\title{
On the Application of Task-based Teaching to College English Writing
}

\author{
Binjie Chen \\ Zhengzhou University of Industrial Technology, Henan, China
}

Keywords: Task-based teaching; English writing; college.

\begin{abstract}
Writing is a process of expression and communication through languages. It is also one of the most effective teaching activities for students to internalize the knowledge of English. This thesis aims to promote the task-based teaching, achieve effective English writing teaching and enhance the ability of students' English writing.
\end{abstract}

\section{Introduction}

Currently, the situation of College English writing is not optimistic. Many College students are not good at English writing, because they lack enough vocabularies and grammars. They have confusion in English writing. Despite that different teaching methods are tried in English writing, the teaching effect is not obvious. The task-based teaching emerged in the 1980s and was composed of language theory, second language acquisition theory and theoretical support of foreign language teaching. The task-based teaching used in College English writing can enhance students' interest in writing and promote practical application of language abilities, so that students are no longer afraid of writing. The task-based teaching is a dynamic development of learning, whose objectives are language teaching and social class. It fully represents the concept of student-oriented education.Developing the task-based teaching will not only depend on predictable factors, such as institutional demands, objectives, class sizes and activities, but also depend on unpredictable factors, such as maturational levels, learner factors, learner goals, and a host of other factors.

\section{Analysis of College English Writing}

\subsection{Importance of English Writing in Colleges}

Writing is important in many ways. Firstly, improving our ability of using words is a basic function of writing. Moreover, writing is an effective way to enlarge our vocabularies. Different compositions require different vocabularies. Therefore, the more compositions we write, the more vocabularies we get. At the same time, it is helpful to enlarge our reading. And last but not the least, writing makes great contribution to our logical thinking and analysis ability. For one thing, to write a good composition, we must collect and arrange writing materials systematically so that we can show off what is essential and what is not so important. In the process of dealing with materials, we are also learning to analyze and deal with the different problems. For another, it is also a process to practice our own thinking ability and form different thoughts. By dealing with all kinds of compositions, we can get in touch with more thoughts and become wiser.

\subsection{Problems about College English Writing}

Writing often leads English teachers to be in a dilemma. They want to teach writing well but they cannot put enough time into teaching in class. The time of class is limited and writing itself is a time-consuming process. In most of the Chinese Colleges, the time of students getting together with their English teachers is limited. However, there is warming up, listening, speaking and others in teaching contents, and they must be taught in a limited time. Thus, the teacher has to shorten the time for students to practice writing. The case is highly concerned about this matter by the teacher and the new national curriculum criteria for English education. Teachers do not have enough confidence to complete the task of teaching writing.

Second, writing teaching in Colleges has been neglected from grade one and two until grade three. In the second term of grade three, writing is influenced by exam-oriented teaching. The purpose of 
writing teaching is to win in the examination. In the classroom, writing teaching is such a process: teachers give some selectical topics to students, and then put forward a series of demands, and finally ask students to complete an essay in a limited time. All teaching activities are only concerned about how to get high scores in exams, and ignore the students' interest and motivation. Many students are tired of this boring tasks and processes. In addition, writing itself is a difficult task, so they have no motivation and they are afraid to write. The result of such kind of writing teaching not only wastes time but also has little influence.

Third, traditional inspection and assessment of the composition does not work well. Compared with the results, feedback components behind the teachers' written comments are not taken seriously enough. In addition, the composition needs to be modified. Thus, the teacher's feedback is not sufficiently effective to improve students' writing skills. Gradually, the students lost interest in writing, and they just complain about their writing proficiency worse.

In addition to the existing problems in the teaching of writing, the problem also exists in the students' writing. For example, their compositions are often poorly organized and underdeveloped. The grammar is awkward. The usage of vocabulary is weak. Student's ideas can not be expressed appropriately.

Fourth, there is a problem in writing phrases and grammars. Most of erroes are related to words and grammars. The main reason for this phenomenon is due to the reasons: on the one hand, students do not have enough words and phrases; on the other hand, students do not fully understand the pragmatic differences among words or phrases. In addition, the syntax is taught as an abstract knowledge, rather than combined into context. Many students memorize a lot of grammar rules and syntax, but there have been endless mistakes when they write sentences. Many syntax errors mainly focuse on the tense, voice, and the number of terms.

Fifth, the writing problem is devoid of sentence variety and content. Although some students are able to write grammartically right, syntactic structures are monotonous and too simple and their compositions are devoid of substance. As far as poor content in writing is concerned, 59\% student's compositions are lack of main ideas and 51\% students are unable to enlarge topic sentences with details. The main reasons are: for one thing, the students only read some books after schools and their knowledge is too narrow; for another thing, they lack the organization strategy. In traditional writing classes, there are a few strategies about writing instruction. Students can imitate models of writing samples. They can not fully express their ideas with a variety of sentences, because they can not fully understand the model, but they mechanically imitate the model.

\section{Theories of Task-based Teaching}

\subsection{Theoretical Basis of Task-based Teaching}

The theoretical basis includes interlanguage theory, second language acquisition theory and constructivism theory. The view of "learning centers" has epoch-making significance to the development of foreign language teaching method. Interlanguage has gone through three stages of development, that is, comparative analysis of the stage in the 1960s and 1970s, interlanguage generation stage, and theoretical models in the 1980s.

Constructivism believes that human activity includes social learning and development individual learners, rather than others. Construction occurred in an environment of interaction with others which is the result of social interaction. Therefore, the society emphasizes the learner's own individual experience background, the construction of objective things, and the subjective sense. The opponent emphasizes on human learning and development, interaction with others, and the ideal scenario where the knowledge can be obtained.

\subsection{Characteristics of Task-based Teaching}

There are many applied linguists who have generalized the characteristics of task-based teaching, such as Skehan and Nunan.

Skehan, synthesized the views of various linguists and then listed the five main characteristics of task-based teaching: "Meaning is primary; Learners are not given other people’s meanings to 
regurgitate; There is some sort of relationship to comparable real-world activities; Task completion has some priority; The assessment of the task is done in terms of outcome." Nunan summarized five ones: "An emphasis on learning to communicate through interaction in the target language; The introduction of authentic texts into the learning situation; The provision of opportunities for learners to focus, not only on language, but also the learning process itself; An enhancement of the learner's own personal experiences as important contributing elements to classroom learning; An attempt to link classroom language learning with language activation outside the classroom.”

In a word, the characteristic of task-based teaching includes all possible aspects, and it provides a lot of rich information.

\subsection{Principles of Task-based Teaching}

Learning a language is ultimately necessary to fulfill the purpose of the actual use of them; therefore, the design task of input material should be derived from real life. The process of writing teaching can give students as much as possible the creation of real life by the use of verbal communication environment. Of course, the 'real' is a relative concept. When the task is designed to guide students in order to achieve the purpose, we can create a more realistic task. With more contact with students, the language input materials can be easier understood. Around the topic of each unit, teachers can design the authenticity of the language tasks.

The ultimate goal of the task is teaching service, so the design task should not only pay attention to the form of the task, but also pay attention to the contents of the task. Setup tasks should guide the students closer to the principle of teaching objectives. With fancy useless tasks, after a lively classroom, students learn the knowledge of nothing, and tasks are meaningless.

Teachers can arouse students' enthusiasm for learning by creating a lively effect of the classroom. Let the students take the initiative to participate in learning through verbal communication. Therefore, fun is a very important factor considered in the task-based teaching. In addition to interesting tasks, there are also other aspects to consider, such as the students' participation, multi-directional communication and interaction, emotional communication, problem solving or completion after the excitement of the mission, a sense of achievement and so on.

\section{Application of Task-based Teaching to College English Writing}

\subsection{Basic Application Modes of Task-based Teaching in English Writing}

At this stage, teachers usually provide brief topics, and students take activities in the topics, such as the review of the learned words and phrases, or learning new words which are closely related the next two phases. The task-based teaching requires students' living and study ex-experiences should be activated in the process of language input before a new topic being shown. In terms of social interaction theory, it is more incentive for students to learn if the new knowledge and skill and previous ones are connected.

In general, the task can be divided into two steps: mechanical practice and meaningful practice. Mechanical approach, so called skills or tasks on behalf of the campaign, focusing on voice, tone, intonation, drills, and grammars, thereby laid the basis for meaningful practice. Meaningful communication between practice and practice in the practice of this process is the transfer of skilled workers from form to content and meaning. This stage is very critical. It will directly affect the development of the task after the event.

In the stage of post-task activity, students are engaged in communicative task by employing knowledge and skill previously learnt and achieved. Activities can be dealt with in one to one or in groups. Post-task activity has four characteristics: life simulation; information gap; problem solving; autonomy and creativity.

\subsection{Specific Application Tasks of College English Writing}

In a comparing task, students are required to identify similarities and differences. This task can develop students' ability of observation. For example, in the English book of Colleges, there is a text Work and Play. There is a topic, three boys are swimming in Picture 1, but they are fishing in Picture 2. The girl is reading a book in Picture 1, but she is listening to music in Picture 2. Four girls are 
singing in Picture 1, but they are flying kites in Picture 2. Three girls are drinking in Picture 1, but they are reading the newspaper in Picture 2. A girl and a boy are playing with a dog in Picture 1, but they are playing cards in Picture 2. Ask students to find out differences.

Comparing task focuses on training the students' ability to observe. College students tend to learn English carelessly. For example, they do not pay attention to details seriously. This task can make up for deficiencies, and gradually develop the students' habits to study seriously.

In problem-solving task, students are required to solve problems they may encounter in life according to the students' own knowledge. For example, for the topic of students' access to the Internet, teachers can ask students to play teachers, parents and students to speak out their views on the Internet. Then students can ask questions, Internet pros and cons, and how to solve the problem, so that students can use the Internet effectively. Each group discusses and writes their views, and gives the show at the same time. At the same time by solving the problem, students can learn empathy problems, and have moral education.

Problem-solving task can cultivate students' ability to solve problems. It aims that whenever they face difficulties, they should find solutions to the problems. During this process, students can experience pleasure and pain, but after they find the solutions, they will have a sense of accomplishment. Then it will promote them to learn new things.

A creative task means any open and exploratory task. For example, there are key words and phrase in each unit. Students can compose the words and phrases into a story or a short text. Some students will write a love story. Students can fully use their imagination and creativity.

A decision-making task requires students to make decisions by discussion. Students can have a discussion to make a choice and reach consensus finally. For example: When December $25^{\text {th }}$, 2015 is approaching, students can discuss whether to hold an English party and write a report on why to hold the English party and where to hold the English party.

In an opinion-exchange task, students are required to express different views on the same thing. For example, in the English book of Colleges, there is a topic about Internet. Some parents think that students' spending too much time online will affect academic performance. Some parents think that Internet can help students increase knowledge and learn more extracurricular knowledge. Then teacher asks students to have a discussion about the topic.

\section{Conclusion}

In summary, task-based teaching to pursue the ideal state requires a large amount of language input and output, as well as authentic use of language. It can greatly stimulate students' intrinsic motivation. By the use of a variety of tasks, students have the opportunity to integrate language learning and focus on the meaning of the expression, thus reducing the learning psychological pressure. The task-based teaching can be applied not only to stimulate students' interest in English writing, but also improve the teaching quality and teaching efficiency. We must pay attention to the task-based teaching, and fully understand the theory of the task-based teaching.

\section{References}

[1]. Beretta, Anna. Implementation of the Bangalore Project. New York: Education Press, 2005.

[2]. Bachman, Lan. Some Reflections on Task-based Language Performance Assessment, Language Testing, Vol. 19(2002).

[3]. Badger, Jatin. A Process Genre Approach to Teaching and Writing, ELT Journal, Vol. 2(2000).

[4]. Carless, Dana. “Implementing Task-based Learning with Young Learners” [J] ELT Journal, Vol. 4(2002).

[5]. Ellis, Raglan. Task-based Language Learning and Teaching. Oxford University Press, 2003.

[6]. Krashen, David. The Natural Approach. Oxford University Press, 2002.

[7]. Littlewood, Willson. Communicative Language Teaching. Cambridge University Press, 2000.

[8]. Nunan, David. Task-based Language Teaching. Cambridge University Press, 2004. 